\title{
Pemikiran Fazlur Rahman Dan Muhammad Arkoun
}

\author{
Ajahari \\ IAIN Palangka Raya \\ ajahari@iain-palangkaraya.ac.id
}

\begin{abstract}
Islam is a religion that has a righteous character li wa kulli zamānin makānin. Islam also has a universal doctrine, meaning that applies overall for all nations, place and circumstances. Islam as a religion with a grounding Qur'an and sunnah in certain respects may experience a variety of interpretations and changes in interpretations according to the context of the times, especially in verses mutashabihat and focused on passages that are muamalah, not the verses which is' ubudiyah. For it is necessary that activities remain perpijak ijtihad to the Qur'an and al-Hadith. All modern thinkers assume that if Islam wants to survive and deal with the modern developments, he must undergo a re-definition, reconstruction and re-actualization. Among the modern Islamic thinkers who ask these thoughts are Fazlur Rahman Malik and M.Arkoun. Fazlur Rahman Malik asserted that the condition of Muslims will not escape from a variety of problems, difficulties and backwardness unless Muslims back and adhering to the Qur'an. Ignoring a past history does not only imply a denial of the existence of history itself, but also can lead people to lose selfexistence and belief systems within the framework of contemporary history.
\end{abstract}

Keywords : Thought, Fazlur Rahman, Muhammad Arkoun

\section{A. Pendahuluan}

Kehadiran agama Islam ${ }^{1}$ yang dibawa oleh Nabi Muhammad saw. diyakini dapat menjamin terwujudnya kehidupan manusia yang sejahtera lahir dan bathin. Terdapat berbagai petunjuk di dalam al-Quran tentang bagaimana seharusnya manusia menyikapi kehidupan ini secara lebih bermakna dalam arti yang luas.

Tema-tema pembicaraan al-Qur'an mengenai berbagai kehidupan manusia merupakan sesuatu yang sangat ideal dan luar biasa. Islam mengajarkan

\footnotetext{
1 Kata Islam berasal dari kata Bahasa Arab "salama" atau "salima". Kata "salama" atau "salima" ini mempunyai arti yang cukup luas. Bisa berarti selama, sejahtera dan damai dan bisa juga berarti tunduk, dalam hal ini penundukan diri kepada hukum Tuhan. Menurut istilah, Islam adalah wahyu atau risalah yang diberikan Allah kepada Nabi Muhammad untuk disampaikan kepada umatnya untuk menjadi pedoman hidup bagi kebahagiaan hidup di dunia dan di akhirat. Lihat : Toyib I.M. dan Sugianto. Islam dan Pranata Sosial Kemasyarakatan, (Bandung: PT. Remaja Rosdakarya, 2002) hal. 23. Lihat juga Abuddin Nata. Metodologi Studi Islam, (Jakarta: Raja Grafindo Persada 1998) hlm.61.
} 
bagaimana menghargai akal melalui pengembangan ilmu pengetahuan dan teknologi, ${ }^{2}$ bersikap hidup yang penuh keseimbangan dalam memenuhi kebutuhan hidup baik material maupun spiritual, ${ }^{3}$ mengajarkan kehidupan yang dinamis dan progresif, ${ }^{4}$ kebebasan beragama, ${ }^{5}$ memiliki kepedulian sosial, ${ }^{6}$ menghargai waktu, ${ }^{7}$ mencintai kebersihan, ${ }^{8}$ mengutamakan persaudaraan, ${ }^{9}$ dan masih banyak lagi petunjuk al-Qur'an mengenai sikap-sikap positif lainnya. Pada prinsifnya antara isi/tema pembicaraan al-Qur'an yang satu dengan yang lain saling mendukung/memperkuat dalam membangun sebuah bangunan alQur'an yang utuh dan konprehensif. Gambaran mengenai Islam dengan seperangkat ajarannya yang ideal di atas sebenarnya dalam lintas sejarah peradaban Islam telah di buktikan oleh para-para cendikiawan dan tokoh-tokoh muslim waktu itu dan bahkan hasilnyapun telah dirasakan oleh semua umat di dunia. ${ }^{10}$

Sejalan dengan pernyataan di atas, Harun Nasution mengatakan bahwa Islam berlainan dengan agama yang pada umumnya diketahui, Islam bukan hanya mempunyai satu atau dua aspek akan tetapi multi asfek antara lain asfek teologi, ibadah, moral, mistisme, filsafat, sejarah, kebudayaan dan sebagainya. Pengetahuan tentang Islam dari satu atau dua aspek dan bahkan dari satu aliran atau mazhab saja akan menimbulkan menimbulkan pengetahun yang tidak lengkap tentang Islam $^{11}$

${ }^{2}$ Q.S. al-Rahmân [55]: 33.

${ }^{3}$ Q.S. al-Qashash [28]: 77.

${ }^{4}$ Q.S. al-Ra'd [13] : 11.

${ }^{5}$ Q.S. al-Kâfirun [109]: 6. dan Q.S. al-Baqarah [2]: 256.

${ }^{6}$ Q.S. al-Mâûn [107] : 1-7.

${ }^{7}$ Q.S. al-Ashr [103]: 1-3.

${ }^{8}$ Q.S. al-Baqarah [2]: 122.

${ }^{9}$ Q.S. al- Hujurat [49]: 13.

${ }^{10}$ Umat Islam di zaman Klasik (650-1250 M.) telah membuktikan dengan jelas misi kemanusiaan dari ajaran Islam. Pada masa itu Islam telah memberikan rahmat dalam bidang ilmu pengetahuan, kemakmuran, peradaban dan sebagainya. Lihat Yusran Asmuni. Dirasah Islamiyah II; Pengantar Studi Sejarah Kebudayaan Islam dan Pemikiran, (Jakarta: PT. Raja Grafindo Persada, 1998), hlm.7-15)

${ }^{11}$ Harun Nasution. Islam di tinjau dari Beberapa Aspeknya, (Jakarta: UI-Press, 1985), hlm. 33. 
Islam sebagai sistem ajaran keagamaan yang lengkap, memberikan tempat pada dua jenis penghayatan keagamaan. Pertama, eksoterik (lahir), yaitu penghayatan keagamaan yang berorientasi pada formalitas fiqhiyah atau pada norma-norma atau aturan-aturan keagamaaan yang ketat. Kedua, esoterik (bathin), yaitu penghayatan keagamaan yang berorientasi dan menitik beratkan pada inti keberagamaan dan tujuan keberagamaan. ${ }^{12}$ Tekanan yang berlebihan kepada salah satu dari dua aspek penghayatan itu akan menghasilkan kepincangan dan menyalahi prinsip ekuilibrium (tawazun) dalam Islam.

Kenyataan Islam sekarang menampilkan keadaan yang jauh dari citra ideal. Ibadah yang dilakukan umat Islam, seperti salat, puasa, zakat, haji dan sebagainya nampaknya berhenti pada sebatas membayar kewajiban dan menjadi lambang kesalehan, buah dari ibadah yang berdimensi esoteris (rohani) yang berimplikasi terhadap prilaku keseharian baik sebagai individu maupun sosial sudah nampak berkurang.

Situasi keberagaman umat Islam secara umum masih cenderung menampilkan kondisi keberagaman yang legalistik formalistic. Agama hanya dimanifestasikan dalam bentuk ritual formal sehingga muncul formalisme keagamaan yang lebih mementingkan "bentuk" dari pada 'isi". Akibatnya agama kurang dipahami sebagai seperangkat paradigma moral dan etika yang bertujuan membebaskan manusia dari kebodohan, keterbelakangan dan kemiskinan.

Akibat dari kesalahpahaman memahami simbol-simbol keagamaan itu, maka agama lebih dihayati sebagai penyelamat individu dan bukan sebagai keberkahan sosial secara bersama. Seolah-olah Tuhan tidak hadir dalam problematika sosial, kendati namanya sering disebut. Pesan spiritual agama menjadi mandek atau terhenti, mengkristal dalam sekumpulan mitos dan

\footnotetext{
${ }^{12}$ Dadang Kahmad. Sosiologi Agama, (Bandung: Remaja Rosdakarya, 2002), hal. 200.
} 
ungkapan simbolis tanpa makna. Agama tidak muncul dalam sebuah kesadaran kritis terhadap situasi aktual. ${ }^{13}$

\section{B. Kajian Pustaka}

Syekh Muhammad Qutb dalam bukunya Subuhat Hawlil Islam yang telah diterjemahkan dalam bahasa Indonesia tahun 1980 dengan judul Salah Paham Terhadap Islam, memberikan gambaran umum tentang Islam yang disalah pahamkan bukan saja oleh orang-orang non muslim, tetapi juga oleh orangorang Islam sendiri . Kesalahpahaman itu disebabkan karena beberapa hal, diantaranya adalah: 1) salah memahami ruang lingkup agama Islam; 2) salah menggambarkan segmen-segmen atau bagian-bagian kerangka keseluruhan ajaran agama Islam dan 3). salah dalam mempergunakan metode pengkajian Islam. ${ }^{14}$ Upaya untuk menghilangkan kesalahpahaman sebagaimana di atas, menurut hemat penulis, perlu diketahui dan diajarkan hakikat Islam, yaitu Islam dari segala aspek dan dimensinya. Upaya tersebut tentu saja memerlukan waktu yang lama. Upaya yang ditempuh adalah : Pertama, Islam hendaknya dipelajari dari sumbernya yang asli yakni al-Qur'an yang memuat wahyu Allah dan alHadis yang berisi sunnah nabi Muhammad Saw. Mempelajari kedua sumber asli ini akan memperkecil salah paham dan memperjelas ruang lingkup Islam secara utuh. Kedua, Islam hendaknya dipelajari secara integral (menyeluruh) bukan secara parsial (sepotong-sepotong). Mempelajari dan memahami Islam secara sepotong-sepotong akan menimbulkan skeptis, bimbang dan penuh keraguan serta pemahaman yang sempit terhadap Islam. Ketiga, Islam dapat dipahami dengan menggunakan berbagai pendekatan atau paradigma disiplin suatu keilmuan dan ini amat memungkinkan bahkan harus dilakukan. Hal ini mengingat Islam dengan sumber ajarannya yang terdapat dalam al-Qur'an dan alSunnah memang bukan hanya memuat masalah akidah, ibadah, akhlak, dan

\footnotetext{
${ }^{13}$ Abudin Nata, Metodologi Studi Islam, Jakarta : Raja Grafindo Persada, 1998, p. 3

${ }^{14}$ Muhammad Daud. Pendidikan Agama Islam, Jakarta, PT. Raja Grafindo Persada, 1998, p. 79
} 
kehidupan akhirat semata, melainkan juga berbicara tentang ilmu pengetahuan, teknologi, sejarah, sosial, pendidikan, politik, ekonomi, kebudayaan, seni, kesehatan dan sebagainya.

Berbagai pendekatan menurut disiplin ilmu tersebut barangkali tidak dapat digunakan pada kajian yang memang aspeknya terbatas, misalnya suatu kajian disiplin ilmu dibahas dengan berbagai disiplin ilmu, jelas akan sulit dan tidak dapat dipaksakan tetapi paling tidak bahasan satu disiplin ilmu tersebut memberikan pemahaman tentang bagaimana bentuk korelasi antara satu ilmu dengan ilmu yang lain untuk saling mendukung dan menguatkan. Para pemikir dan ilmuan muslim belakangan ini dengan mempergunakan berbagai pendekatan mencoba melihat bagaimana sesungguhnya potret Islam. Menurut Harun Nasution yang dikutip Didin, apabila dibedakan, dalam ajaran Islam terdiri dari dua hal pokok, yaitu pertama ajaran Islam yang absulot, mutlak, dan tidak boleh mengalami perubahan, kedua, ajaran Islam yang boleh mengalami perubahan dan penafsiran baru sesuai dengan kontek zaman. Pokok yang pertama adalah alQur'an dan Hadis Nabi. Menurutnya, pokok yang pertama ini disebut ajaran dasar, ini tidak dapat diubah, harus diterima apa adanya. Barang siapa yang mengubah firman Allah dan Hadis Nabi, maka dia termasuk orang yang berdusta. Tetapi untuk pokok yang kedua, maka terbuka ijtihad atau pemikiran dan penafsiran. ${ }^{15}$ Orang yang bersungguh-sungguh berijtihad disebut Mujtahid. Mujtahid yang bersungguh-sungguh tidak akan menghasilkan hasil ijtihad yang absulot, mutlak dan seratus persen pasti benar. Mengapa,? karena tentu saja hasil pemikiran manusia sangat terbatas, tidak sempurna dan relative. ${ }^{16}$ Hasil ijtihadnyapun tidak terlepas dari pengaruh lingkungan, sosiokultural tempat ia tinggal, faktor politik, yang dia dukung, latar belakang pendidikan, keluasan wawasan, dan pengetahuan, latar belakang mazhab, dan kecendrungan pemikiran yang ia anut.

15 Ibid,

${ }^{16}$ QS. Al_Isra [15]: 85 "... dan tidaklah kamu diberi pengetahuan kecuali sedikit". 
Pada tataran Islam yang kedua ini muncul pemikirian-pemikiran modern dalam Islam. Pemikiran modern ini muncul sebagai akibat adanya penafsiran baru atas ayat al-Qur'an dan Hadis Nabi yang dicoba untuk "disesuaikan" dengan perkembangan baru yang ditimbulkan oleh kemajuan yang dibawa oleh bangsa Barat.

Semua pemikir modern berasumsi bahwa kalau Islam ingin survive dan berhadapan dengan perkembangan modern, ia harus mengalami re-definisi, rekonstruksi dan reaktualisasi. Bagaimana mewujudkan pemikiran yang hasilnya dapat membuat Islam bertahan dalam zaman modern ini Inilah yang digagas oleh para pemikir yang akan dicoba diuraikan dalan tulisan ini.

Perlu diingat bahwa belum tentu apa yang digagas oleh para pemikir ini benar, Hal ini mengingat karena semua itu hasil ijtihad, hasilnya relatif. Tidak ada yang dapat memutlakkan kebenaran hasil ijtihad mereka, karena itu mereka mengakui bahwa apa yang mereka gagas bersifat tentatif. Kelebihan mereka adalah berhasil merumuskan pemikiran mereka dengan jelas dan terbuka. Mereka suka berdialog dengan siapapun atas dasar tawâshau bil haqqi. Mereka juga mengakui bahwa suatu saat pemikiran mereka akan gugur oleh generasi berikutnya, dan hal ini sah-sah saja. ${ }^{17}$ Dilihat dari wacana pemikiran mereka, menurut Didin Saefuddin, dapat dikategorikan, pertama, mereka mencoba untuk menggagas pemikiran bebas dengan melepaskan diri dari ikatan-ikatan nash. Ini dapat kita lihat pada pemikiran Muhammad Iqbal, Sayyed Amir Ali, Taha Husain, Fazlur Rahman, Muhammad Arqun, Hasan hanafi, Nurchalis Madjid. Kedua, mereka menempatkan ayat-ayat al-Qur'an secara konsepsional dalam kehidupan keberumatan, seperti Jalaluddin al-Afghani, Muhamad Abduh, Sayyed Husein Nasr, Ali Syari'ati, dan Ismail al-Faruqi. Ketiga, mereka mencoba untuk menerapkan pesan-pesan al-Qur'an secara idealogis sesuai dengan konteks zamannya, seperti terlihat pada Abu 'Ala al-Maududi, Sayyid Quthb, Ayatullah

${ }^{17}$ Didin Saifuddin, Biografi.., p. 3. 
Khomaini, dan Muhammad Nasir. Kelompok pertama dipresentasikan oleh cendikiawan, kelompok kedua dipresentasekan oleh para pemikir aktivis, dan ketiga oleh pemikir praksis. Kelompok pertama dapat dimasukkkan dalam pemikiran Liberal, kedua pemikiran konsepsional dan ketiga pemikiran ideologis. ${ }^{18}$ Tulisan ini mencoba untuk mendiskripsikan pemikiran dua tokoh yang dikelompokkan oleh Didin sebagai kelompok yang mempunyai pemikiran liberal yakni Fazlur Rahman dan Muhammed Arkoun.

\section{Metode Penelitian}

Penelitian ini menggunakan jenis pendekatan penelitian kualitatif deskriptif. Menurut Nasir pendekatan kualitatif deskriptif adalah suatu metode dalam meneliti sekelompok manusia, suatu objek bahkan suatu sistem persepsi atau kelas peristiwa pada masa sekarang bertujuan untuk menggambarkan secara sistematis, faktual dan akurat mengenai fakta-fakta

\section{Pembahasan}

Fazlur Rahman adalah sosok pemikir muslim yang sering disebut sebagai tokoh neomodernisme. ${ }^{19}$ Ia lama hidup di Amerika setelah diusir dari Negara asalnya Pakistan, karena diangap melawan arus dengan pemikiran pemikiran yang dianggap liberal. Ia lahir tahun 1919 M disebelah Barat Laut Pakistan dan meninggal tahun 1988 di Amerika Serikat. Ia berasal dari keluarga yang taat beragama dalam mazhab Hanafi. Ayahnya seorang ulama terkenal lulusan Sekolah Tinggi Deoband.

Meskipun ia dibesarkan dalam tradisi mazhab Hanafi, sejak umur belasan tahun ia telah mengembangkan pemikirannya secara bebas. Sejak kecil ia telah bersikap skeptis terhadap pelajaran Hadis yang diberikan ayahnya. Sikap tersebut barangkali merupakan warisan Ahmad Khan dan gerakan Aligarh-nya kepada modernisme Islam yang belakangan di kembangkan oleh Rahman, serta

18 Ibid.,

19 Neomodernisme adalah pola pemikiran yang menggabungkan dua faktor penting, yakni modernisme dan tradisionlisme. Lihat Fachri Ali dan Bahtiar Effendi, Merambah Jalan Baru Islam, Bandung, Mizan, 1986 p.. 175 
disusunnya secara sistimatis dalam karya-karya intelektualnya. Setelah menamati pendidikan menengah, dia melanjutkan studinya ke Universitas Punjab, dan memperoleh gelar M.A. dalam sastra Arab tahun 1942. Tahun 1946, Rahman melanjutkan studi doktoralnya ke Oxford University di Inggris, dan berhasil meraih gelar doktor filsafat pada tahun 1951. Setelah itu ia mengajar selama bberapa tahun di Durham University, Inggris, kemudian Institute of Islamic Studies, McGill University, Canada, dimana ia menjabat sebagai Associate Professor of Philoshofhy. Ketika di Kanada, ia menjalin persahabatan dengan Wilfred Cantwel Smith, seorang orientalis kenamaan, yang sat itu menjabat sebagai direktuir Institute of Islamic Studies. Di awal tahun 60-an, Rahman kembali ke Pakistan dan menjabat selama beberapa waktu sebagai salah seorang staf senior pada Institute of Islamic Research. Di negaranya ia aktif melontarkan pemikiran dan gagasan-gagasannya. Ia sangat kritis terhadap pemikirian keagamaan para modernis pendahulunya, apalagi terhadap kalangan tradisionalis dan fundamentalis

Kritik-kritik Rahman semakin pedas ketika ia mengemukakan pandangan tentang definisi "Islam" Pakistan, terutama terhadap pandangan kaum tradisionalis dan fundamentalis. Pandangan-pandangan tentang al-Qur'an, Hadis dan hukum-hukum tentang berbagai masalah, menimbulkan kontroversi yang semakin berkepanjangan dan berskala nasional. Puncak kontraversinya adalah ketika Rahman mengemukakan bahwa al-Qur'an adalah firman Tuhan, dalam arti kata yang biasa, juga seluruhnya adalah perkataan Muhammad. ${ }^{20}$

Pandangannya membuat heboh selama satu tahun di media massa Pakistan. Kalangan ulama menunduhnya sebagai orang yang telah mengingkari al-Qur'an. Protes massa ditumpahkan di jalan-jalan sampai terjadi mogok massal secara besar-besaran. Sadar dirinya tanpa dukungan, akhirnya ia melepaskan seluruh jabatannya di Pakistan dan kemudian hijrah ke Chicago, Amerika

${ }^{20}$ Fazlur Rahman, Islam, Bandung, 2000, p. 33 
Serikat. Sejak tahun 1970, ia menjabat sebagai guru besar Kajian Islam di Universitas of Chicago.

Setelah kepindahannya Fazlur Rahman telah merasa memperoleh kebebasan intelektual dan dari sanalah ia menyurun pemikiran-pemikiran tentang pembaharuan dalam Islam, dan banyak mahasiswa muslim yang belajar kepadanya. Selain memberikan kuliah dan kajian keislaman, dia juga aktif dalam berbagai kegiatan intelektual seperti memmimpin proyek penelitian, mengikuti seminar internasional, memberikan ceramah di berbagai pusat studi terkemuka. Ia juga aktif menulis berbagai buku ke Islaman dan menyumbangkan artikel keberbagai Jurnal Internasional. Karya-Karyanya mencakup hampir seluruh studi Islam, normative, histories, dan dia mulai mengidentifikasi diri sebagai neomodernis sehubungan dengan usaha pembaharuan yang tengah dilancarkan..

Syafi'i Ma'arif dalam pengantarnya menyatakan mengatakan bahwa pada diri Rahman "berkumpul ilmu seorang alim yang alim dan ilmu seorang orientalis yang paling beken". ${ }^{21}$

Di Indoensia, terdapat tiga murid Fazlur Rahman, yaitu Nurchalish Madjid, Amien Rais, dan M. Syafi'i Ma'arif. Menurut Nurchalish Madjid, Rahman mampu dengan cermat membaca teks-teks klasik perbendaharaan keilmuan Islam di segala bidang, dan ia menilai betapa kunonya Bahasa Arab yang digunakan. ${ }^{22}$

Menurut Madjid, Fazlur Rahman adalah juga seorang pemikir dengan keberanian intelektual yang mencengangkan, bukan saja ia tidak takut kepada kotroversial, bahkan ia melihat bahwa kontroversial adalah bagian dari konsekwensi dan kreativitas intelektual yang acapkali memang tidak mungkin dihindari.

\footnotetext{
${ }^{21}$ Ahmad Syafi'i Ma'arif (pengantar) Fazlur Rahman, Islam, Bandung, 2003, p. vi

${ }^{22}$ Nurchalish Madjid, Fazlur Rahman dan Rekonstruksi Etika Al-Qur'an, dalam Jurnal Islamika, no. 21993.
} 
Muridnya yang lain bernama Wan Moh. Nor Wan Daud memberi kesaksian. Ia bertanya kepada Rahman tentang penggunaan cara yang controversial ini. Rahman tersenyum dan menjawab "Muhammad Nor, umat Islam telah terlena hamper ratusan tahun, kalau anda mau membangunkannya seharusnya, anda menggunakan shock treatment dan bukan dengan cara yang lemah lembut". ${ }^{23}$

Keuletan Rahman dalam kerja ilmiahnya jelas tergambar dari keadaan perpustakaannya di Basement rumahnya. Disitulah dia banyak menghabiskan waktunya. Anggota keluarganya mengatakan bahwa beliau jarang seklai menaiki lantai atas rumahnya, kecuali untuk beberapa keperluan. Beliu sendiri sambil bercanda menggambarkan dirinya seperti seekor ikan yang naik ke atas hanya untuk mendapatkan udara. ${ }^{24}$ Tugas Rahman hanya membaca, mengajar dan menulis.

Rahman tidak suka menggunakan metode kebenaran ganda (double truth methodology) yang sering digunakan sebagian cendikiawan Islam masa lalu, terutama para filosof, yaitu kebenaran kelas awam dan kebenaran kelas elit. ${ }^{25}$

Fazlur Rahman amat kritis terhadap pemikiran Islam yang tidak berakar dari sejarah dan tidak relevan bagi perkembangan masyarakat. Sikap ini mungkin juga disebabkan oleh minat dan kecendrungan intelektualnya sendiri, ia memandang bahwa suatu bentuk pengembangan pemikiran Islam yang tidak berakar dalam kejayaan pemikrian Islam klasik atau luput dari kemampuan menelusuri benang kesinambungan dengan masa lalu adalah tidak aotentik. ${ }^{26}$

Pengembangan pemikiran Islam yang tidak melihat kontinuitas dengan masa lalu, Islam akan kehilangan aotensitasnya yang berakibat akan tidak mampu mengembangkan dinamika internalnya serta tidak sanggup bertahan

${ }^{23}$ Wan Muhammad Nor Wan Daud, "Fazlur Rahman, Kesan seorang Murid dan Teman". Jurnal Ulumul Qur'an, No. 8 tahun 1991.

${ }^{24}$ Ibid., p. 108

${ }^{25}$ Didin Saifuddin, Biografi Intelektual ..., p. 146-149

${ }^{26}$ Madjid, Fazlurrahman dan Konstruksi..., p. 24. 
karena kekurangan segi kemantapan. Pemikiran yang goyah seperti itu akan mudah kehilangan energi, dan dengan begitu juga berarti terancam untuk lekas padam. Disamping itu mengabaikan sejarah masa lalu tidak saja mengisyaratkan pengingkaran akan eksistensi sejarah itu sendiri, tetapi juga bisa mengakibatkan diajukannya pertanyaan serius tentang eksistensi diri sendiri dan sistem keyakinan sendiri dalam kerangka sejarah masa kini. Maka dalam hal itu Fazlur Rahman adalah orang yang sangat teguh memegang prinsip "memelihara yang lama yang baik, dan mengambil yang baru yang lebih baik".

Menurut para pemerhati pemikiran Islam, Fazlur Rahman adalah tokoh yang pemikirannya dikategorikan sebagai neomodernisme yaitu suatu pola pemikiran yang menggabungkan antara pemikiran modern dan tradisional. Modernisme menurut pola ini, bukanlah sesuatu yang harus ditolak, melainkan dengan modernisme bukan pula berarti alam pemikrian tradisionalisme harus dikesampingkan. Hal ini tentunya sejalan dengan pemikiran Islam Fazlur Rahman yang senantiasa dalam mengembangkan pemikirannya melihat perkembangan pemikiran masa lalu.

Dalam beberapa hal, bahkan kedua alam pemikiran (modernisme dan tradisionalisme) bisa berjalan seiring. Apabila orang mengkuti jalan pemikiran Fazlur Rahman dalam seluruh karyanya menurut Syafi'i, Ma'arif, orang akan tahu bahwa ia sangat berkepentingan mengembangkan kembali kesadaran umat Islam akan tanggung jawab sejarahnya dengan pondasi moral yang kokoh. ${ }^{27}$

Pondasi ini hanya mungkin diciptakan apabila al-Qur'an sebagai sumber ajaran moral yang sempurna dipahami secara utuh dan padu. Pemahaman yang benar dan utuh ini harus dikerjakan melalui suatu metodologi yang dapat dipertanggungjawabakan secara agama dan secara ilmu. Menurut Rahman, tanpa suatu metodologi yang akurat dan benar, pemahaman terhadap kandungan alQur'an boleh jadi menyesatkan, apalagi bila didekati secara parsial dan terpisah.

${ }^{27}$ Ahmad Syafi'i Ma'arif, (kata pengantar), Islam dan Modernitas, Bandung, Mizan, 1995, p. v. 
Rahman juga menambahkan bahwa Al-Qur'an dan keagamaan Islam (normativitas dan historisitas) yang sholihun likulli zaman wa makan, harus dilihat dari dua sisi secara utuh sebab jika tidak demikian akan terjadi proses dominasi yang satu atas yang lain, sehingga menepikan aspek "historis" kemanusiaan atau sebaliknya akan menepikan aspek "normativitas" yang dihayati oleh para pemeluk agama. ${ }^{28}$

Fazlur Rahman membagi dialektika pembaharuan di dunia Islam kedalam empat gerakan, yakni revivalisme pramodernis, modernis klasik, neorevivalisme atau revivalisme pasca modern dan neomodernisme. ${ }^{29}$

Gerakan revivalisme modern berusaha mengembalikan ajaran Islam kepada kemurniannya. Gerakan ini disebut juga gerakan pemurnian, yang muncul pada abad ke 18 dan 19 di Arabia, India dan Afrika. Gerakan ini murni muncul dari dalam, tanpa campur tangan pihak Barat, dan bertujuan untuk kembali kepada ajaran Islam sejati, menghilangkan tahayul-tahayul paham tarekat dan memecahkan kebekuam mazhab-mazhab hukum dengan menjalankan ijtihad. Contoh gerakan dengan corak ini adalah gerakan Wahabiyah di Saudi Arabia, Syakh Waliyullah di India, dan gerakan Sanusiyah di Aprika Utara. ${ }^{30}$

Gerakan modernisme klasik muncul pada pertengahan abad ke-19 dan awal abad ke-20, dengan mengambil dasar pembaharuan revivalisme modernis dan berada dibawah pengaruh ide-ide Barat. Gerakan ini mengembangkan isi ijtihad, seperti hubungan antara akal dan wahyu, pembauran sosial, khususnya dalam bidang pendidikan dan status wanita, pembauran politik dan bentuk-bentu pemerintahan yang refresentatif serta konstitusional. Kesemuanya terjadi karena

${ }^{28}$ Dr. Amin Abdullah, Falsafah Kalam di Era Postmodern, Yogyakarta, Pustaka Pelajar, 1997, p. 19-20.

29 Taufik Adnan Kamal, Metode dan Alternatif Neomodernisme Islam Fazlur Rahman, Bandung, Mizan, 1989, p. 18

${ }^{30}$ Fazlurrahman, Membuka Pintu Ijtihad, Bandung, Pustaka, 1984, p. 111 yang dikutip oleh Didin Saefuddin, Biografi Intelektual..., p. 152. Lihat juga Fazlur Rahman, Islam, Bandung, 2003, cet. V, p. 69-70 
kontak dengan pemikiran dan masyarakat Barat. Menurut Rahman usaha modernisme klasik dalam mengaitkan pranata-pranata Barat dengan tradisi Islam melalui al-Qur'an dan Sunah Nabi merupakan prestasi besar. Sunnah Nabi disini diartikan sebagai sunnah historis, yaitu biografi Nabi, bukan Sunnah teknis yang terdapat dalam hadis-hadis yang non histories ${ }^{31}$. Modernisme klasik bersikap skeptis terhadap hadis-hadis, tetapi sayang tidak ditopang oleh kritisme ilmiah.

Neo-Revivalis adalah kelompok intelektual yang muncul sebagai reaksi terhadap modernisme klasik. Berbeda dengan modernisme klasik, yang muncul terutama sebagai masalah pemikiran liberal Islam yang individual, neorevivalisme timbul terutama dalam bentk gerakan-gerakan sosial politik yang terorganisasi. Kelompok ini bangkit dalam pertengahan abad ke 20 di Arab Timur Tengah, anak Benua India Pakistan dan Indoensia. Selanjutnya Neomodernisme merupakan istilah yang diajukan oleh Fazlur Rahman sebagai reaksi atas orang-orang yang mengoreksi kelemahan-kelemahan modernis, revivalis dan tradisional. Tradisionalis adalah orang yang memegang pemikiran ulama abad pertengahan tanpa mengadakan suatu usaha untuk pergantian yang bermakna termasuk dalam merespon masalah-masalah sosial dalam masa kontemporer. Secara umum mereka menganggap pintu ijtihad telah tertutup, karena itu ajaran Islam melalui mazhab yang telah ada. Mereka juga menganggap ulama-ulama sekarang tidak mampu melakukan ijtihad karena tidak memiliki kemampuan , kepandaian dan ilmu setingkat ulama-ulama pemimpin mazhab dimasa lalu, lagi pula seluruh kehidupan manusia yang berhubungan dengan hukum agama telah lengkap diijtihad dan ditulis oleh ulama terdahulu. ${ }^{32}$

Dari hasil karya-karyanya, terutama tema yang berjudul Tema Pokok AlQur'an, Tampak jelas bahwa Rahman ingin mendasarkan pandanganpandangannya terutama pada al-Qur'an.

\section{Ibid.,}

${ }^{32}$ Lihat M. Hasbi Amirudin, Konsep Negara menurut Fazlur Rahman, (pengantar) Deliar Noer, Yogyakarta, UII Press, 2000, cet. Ke-1, hlm. 16-23. 
Ia mengatakan bahwa al-Qur'an bukanlah karya misterius atau karya sulit yang memerlukan manusia terlatih secara teknis untuk memahami dan menafsirkan perintah-perintahnya. Sebab bila demikian kitab ini tidak akan dialamatkan kepada komunitas secara luas. Ada dua prosedur yang benar untuk memahami al-Qur'an, yaitu, Pertama, seseorang harus memepelajari al-Qur'an dalam ordo histories untuk mengapresiasi tema-tema dan gagasan-gagasannya, Sebab bila tidak seseorang boleh jadi akan tersesat dalam memahami beberapa butir penting tertentu dari ajarannya. Kedua, seseorang harus mengkajinya dalam konteks latar belakang sosio-historisnya. Tanpa memahami latar belakang mikro dan makronya secara memadai, menurut Rahman, besar kemungkinan seseorang akan salah tangkap terhadap élan dan maksud al-Qur'an serta aktivitas Nabi baik di Makkah maupun di Madinah. ${ }^{33}$

Perhatian Rahman terhadap al-Quran begitu intens. Madjid menceritakan pengalamannya. Sedemikian besarnya perhatian Rahman terhadap kitab suci, kata Madjid, sampai-sampai dalam kuliah ia tampak amat at home jika ia menerangkan makna sebuah firman, dengan referensi berbagai sumber klasik, dan dengan percobaan tak kenal lelah dalam mencari relevansinya untuk masalah-masalah kontemporer. Jika ada ungkapan sangat ringkas tentang Fazlur Rahman dan keseluruhan pandangannya hidupnya, tulis madjid, itu adalah bahwa ia seorang "Qur'anic" setulustulusnya dalam perspektif kritik sejarah yang amat kompeten. Tidak jarang pula Fazlur rahman memperagakan pandangannya itu dengan mengangkat tinggi-tingi sebuah mushaf sambil berseru

${ }^{33}$ Lihat Ahmad Syafi'i Ma'arif (pengantar) Fazlur Rahman, Islam, Bandung, 2003, p. viii 
"Kaum muslimin tidak akan lepas dari kesulitannya sekarang, kecuali jika mereka kembali dan berpegang pada ini. ${ }^{34}$

Rahman mengatakan bahwa semangat dasar adalah moral dan kesan yang paling intens yang ditinggalkan al-Qur'an bagi pembacanya bukanlah berupa Tuhan yang selalu mengawasi, merenggut dan menghukum, sebagaimana dibuat orang-orang Kristen, bukan pula gambaran seorang hakim utama sebagaimana ulama-ulama Fiqh Islam cendrung memikirkannya, tetapi adalah suatu kehendak yang bertujuan dan terpadu yang menciptakan tata tertib dialam semesta, sifat-sifat kekuasaan atau keagungan, kewaspadaan atau keadilan serta kebijaksanaaan yang diatributkan Tuhan di dalam al-Qur'an dengan penekanan yang jelas, pada kenyataannya adalah kesimpulan-kesimpulan yang paling tepat, dapat diambil dari keteruturan kosmos yang kreatif. Rahman menjelaskan al-Qur'an muncul sebagai suatu dokumen yang dari awal hingga akhir memberikan semua tekanan-tekanan moral, yang perlu bagi tindakan-tindakan manusia yang kreatif dan sungguh kata Rahman kepentingan sentral al-Qur'an adalah pada manusia dan perbaikannya. ${ }^{35}$

Seluruh karya tulis Rahman dialirkan untuk bermuara kepada penyingkapan kandungan kitab suci. Karya-karya itu juga dapat dipandangan sebagai saripati penyimpulan yang dibuatnya berdasarkan pengetahuan yang mendalam dan meluas tentang pemikiran Islam, disamping wawasan dan pengalamannya sebagai orang yang hidup di dunia dan zaman modern ${ }^{36}$

\footnotetext{
${ }^{34}$ Madjid, Fazlur Rahman, Rekonstruksi..,, yang dikutip Didin Saefuddin, Biografi Intelektual..., p. 153

${ }^{35}$ Fazlur Rahman, , Islam, Bandung, 2003, cet. V, p. 40

${ }^{36}$ Ibid., p. 48
} 
Rahman menganggap perlu untuk mengembangkan beberapa peralatan ilmiah untuk mengontrol kemajuan ilmu tafsir al-Qur'an. Menurutnya ada 3 peralatan yang harus dikuasai setiap orang yang akan menafsirkan al-Qur'an, Pertama, tidak hanya pengetahuan tentang bahasa saja yang diperlukan untuk memahami al-Qur'an secara tepat, tetapi juga tentang idiom-idiom Bahasa Arab. Dari sini berkembang gramatika Bahasa Arab, ilmu perkamusan, dan kesusasteraan Arab. Kedua, latar belakang turunnya ayat-ayat Al-Qur'an (asbabun nuzul). Ketiga, tradisi hostoris yang berisi laporan tentang bagaimana orang dilingkungan Nabi memahami perintah-perintah al-Qur'an. Setelah persyaratan-persyaratan tersebut terpenuhi, barulah penggunaan nalar manusia diberi tempat. ${ }^{37}$

Ia memberi beberapa persyaratan metodologis dalam memahami dan menafsirkan al-Qur'an yaitu sebagai berikut :Dalam menemukan makna teks alQur'an, harus digunakan pendekatan historis yang menempatkan al-Qur'an dalam tatanan kronologis sejarah. Harus dibedakan antara ketetapan-ketetapan legal alQur'an dan sasaran-sasaran serta tujuan-tujuan dari ayat yang diturunkan. Harus dipertimbangkan faktor-faktor yang menjadi latarbelakang sosiologis sehingga dapat dihindarkan penafsiran-penafsiran yang subyektif. Pemahaman dan penafsiran al-Qur'an harus dilakukan dengan penyajian yang padu, dan merupakan satu-satunya cara bagai para pembaca untuk memperoleh apresiasi yang tepat mengenai al-qur'an, perintah Tuhan kepada manusia. ${ }^{38}$ Disamping menganggap perlunya metodologi tafsir yang sistimatis, Fazlur Rahman menekankan perlunya pemahaman kembali tentang sumber-sumber hukum Islam, yaitu al-Qur'an, Sunnah dan Hadis Nabi, Ijtihad dan Ijma. Dengan demikian akan menjadi jelas relevansinya dengan kehidupan zaman sekarang, khususnya dalam menetapkan masalah-masalah hukum Islam.

\footnotetext{
37 Ibid.,

${ }^{38}$ Fazlur Rahman, Tema Pokok Al-Qur'an, Bandung : Mizan, 1983, p. x
} 
Menurut Fazlur Rahman, kendatipun tidak menyatakan secara gamblang pendapatnya mengenai konsep Islam mengenai Negara (pemerintahan), nampaknya lebih cendrung berpendapat bahwa Islam tidak mengajarkan secara jelas mengenai sistem kenegaraan tetapi mengakui bahwa terdapatnya sejumlah tata nilai dan etika dalam al-Qur'an. Kendatipun Nabi Muhammad tidak pernah menyatakan dirinya sebagai pemimpin negara, tetapi dia telah menjadikan negara sebagai alat bagi agama Islam untuk menyebarkan dan mengembangkan agama. Fazlur Rahman lebih tegas menyatakan bahwa "antara agama dan politik tidak bisa dipisahkan. ${ }^{39}$

Fazlur Rahman juga menyatakan bahwa Islam memerintahkan agar persoalan-persoalan kaum muslimin ditanggulangi melalui syura atau konstitusi timbal balik. Seperti diketahui bahwa syura merupakan salah satu perintah Allah kepada kaum muslimin dalam menyelesaikan persoalan-persoalan umat yang terdapat banyak dalam al-Qur'an dan Hadis-hadis Nabi Saw. Dalam al-Qur'an misalnya terdapat dalam surat Ali-Imran ayat 159 dan al-Syu'ara ayat 38. Dalam penjelasannya mengenai syura ini Fazlur Rahman juga menunjuk ayat-ayat lain sebagai penjelasnya sebagai bentuk syura seperti surat al-Ashr ayat 3, alMujâdalah ayat 8 dan 58 serta al-An'am ayat 2.

Nilai dan etika dalam bentuk syura ini telah dijadikan sebagai dasar dalam penyelenggaraan Negara oleh Fazlur Rahman. Ia juga menegaskan bahwa kebebasan untuk mengemukakan pendapat dan kritik yang konstruktif yang ditujukan kepada pemerintah dianggap sebagai tugas keagamaan.

Ketika Fazlur Rahman menjelaskan etika dalam menegakkan sosiopolitik dia telah menjadikan ayat-ayat al-Qur'an surat al-Hajj ayat 40 dan Ali Imran ayat 110 sebagai dasar pijakannya. Untuk menjelaskan keharusan

${ }^{39}$ Lihat. M. Hasbi Amirudin, Konsep Negara menurut Fazlur Rahman, (pengantar) Deliar Noer, Yogyakarta, UII Press, 2000, cet. Ke-1, hlm. 80. 
menciptakan keadilan serta sikap berlaku adil dalam penyelenggaraan negara ia telah berusaha mengutip ayat-ayat al-Qur'an seperti surat al-Nisâ ayat 58, alMâidah ayat 51. Ketika menjelaskan bahwa umat dibenarkan mengkritik pemerintah ia menunjuk surat al-Nisa ayat 83. Tetapi tidak dibenarkan sikap yang bernada subversive dan yang dapat menimbulkan kebencian serta menghasut rakyat untuk menggulingkan pemerintahan yang sah dengan cara-cara yang tidak konstitusional dan dengan menanamkan perasaan putus asa kepada rakyat.

Dalam hubungan dengan hubungan internasional sebuah negara Islam yaitu untuk menciptakan perdamaian, ia mengutip ayat 207 surat al-Baqarah, dan ayat 13 surat al-Mâidah, untuk menjelaskan kewajiban bagi sebuha Negara Islam untuk menepati janji yang telah dibuat dalam hubungan internasional ia mengutip ayat 7 surat al-Taubah.

Memperhatikan tulisan-tulisan Fazlur Rahman mengenai kenegaraan nampaknya dia berkesimpulan bahwa al-Qur'an telah mengajarkan beberapa etika dan nilai dalam kehidupan bernegara bagi umat manusia.. Ini terlihat dari penyajiannya, setiap menjelaskan bagaimana seharusnya umat bertindak dalam hubungannya dengan kehidupan bernegara selalu menggunakan pedoman ayatayat al-Qur'an.

Fazlur Rahman menaruh perhatian yang besar terhadap pembaharuan pendidikan Islam. Menurutnya salah satu pendekatan pembaharuan pendidikan adalah dengan menerima pendidikan sekular modern seperti yang telah berkembang pada umumnya di Barat dan mencoba untuk "mengislamkan"nya, yakni dengan mengisinya dengan konsep-konsep kunci tertentu dari ajaran Islam. ${ }^{40}$ Pendekatan ini memiliki dua tujuan, yaitu pertama, membentuk watak pelajar-pelajar dengan nilai Islam dalam kehidupan individu dan masyarakat, dan kedua, untuk memungkinkan para ahli yang berpendidikan modern untuk

${ }^{40}$ Fazlur Rahman, Islam dan ..., p. 155-156 
memahami bidang kajian masing-masing dengan nilai-nilai Islam pada perangkat-perangkat yang lebih tinggi, menggunakan perspektif Islam untuk mengubah, baik kandungan maupun orientasi kajian-kajian mereka. Bila tidak ada usaha untuk mewarnai pendidikan dengan orientasi Islam, maka kata Rahman, pandangan mahasiswa kita tidak dapat tidak akan tersekularkan atau kemungkinan besar mereka akan membuang orientasi Islam apapun yang pernah mereka miliki. ${ }^{41}$ Dalam hal ini nampaknya Rahman mendukung ide Islamisasi Ilmu Pengetahuan ${ }^{42}$. Menurutnya, upaya menamakan watak Islam dalam diri pelajar-pelajar muslim tidak akan berhasil apabila bidang-bidang ilmu pengetahuan pada taraf yang lebih tinggi dibiarkan sepenuhnya sekuler, yaitu tanpa tujuan dalam kaitannya dengan efeknya bagi masa depan umat manusia. ${ }^{43}$

Muhammad Arkoun merupakan salah seorang pemikir Islam yang berasal dari Al-Jazair. Muhammad Arkoun hidup dalam tiga dunia: Arab, Islam dan Eropa. Ia dilahirkan pada tangal 2 Januari 1928 di kaki bukit desa Berber, Taorirt-Mimoun, Suku Kabylia. Keluarganya berasal dari masyarakat tingkat bawah. Desanya sendiri berada di pinggiran budaya dan politik dominan Aljazair, negeri yang jauh dari pusat dunia Arab dan Islam. Ia merupakan seorang anak pedagang rempah-rempah yang tumbuh menjadi seorang sarjana dan pemikir internasional yang terbilang sangat sukses. Dengan bahasa Barber, ia mempelajari bahasa Perancis sebagai bahasa kedua, kemudian bahasa Arab sebagai bahasa ketiga. ${ }^{44}$ Ia merupakan seorang sosok pemikir Islam yang terlibat

${ }^{41}$ Ibid, p. 156

${ }^{42}$ Ismail al-Faruqy mendefinisikan pengertian Islamisasi ilmu sebagai suatu usaha untuk mengancukan kembali ilmu, yaitu untuk mendefinisikan kembali, menyusun ulang data, memikirkan kembali argumentasi dan rasional iasi berhubungan data itu, menilai kembali kesimpulan dan tafsiran , membentuk kembali tujuan dan melakukannya secara yang membolehkan disiplin itu memperkaya fisi dan perjuangan Islam. Lihat tulisan Rosnani Hasyim, Gagasan Islamisasi Ilmu Pengetahuan Kontemporer, dalam Majalah Pemikiran dan Peradaban Islam "Islamia" tahun I, no.6 Juli-Desember, 2005, p. 35-36

${ }^{43}$ Fazlur Rahman, Islam dan ..., p. 156.

${ }^{44}$ Dr. Muhamad Arkoun, Rethingking of Islam, (penerjemah) Yudian W. Yasmin dan Lathiful Khuluq, Yogyakarta, LPMI dan Pustaka Pelajar, 1996, cet. I, p. x. Untuk selanjutnya Nama yang bersangkutan di sebut M. Arkoun. 
dalam menafsirkan dan menyusun kembali tardisi-tardisi keagamaan, Fiqh dan pemikiran filosofis klasik melalui sistem hermeneutis yang terilhami oleh metodologi kritis Barat kontemporer. ${ }^{45}$ Dia memulai studi Bahasa Arab di negara kelahirannya dan menawarkannya di Paris. Dia bertugas di Sorbone sebagai propesor sejarah pemikrian Islam dan pernah menjadi Direktur Studi Arab dan Islam. Kemudian Dia juga menjadi editor jurnal ilmiah berbahasa Prancis, Arabica, selama bertahun-tahun. Reputasi internasional Arkoun menyebabkan ia diundang untuk memberikan kuliah di berbagai instutusi akademik di seluruh dunia, termasuk di Institut Studi Lanjut di Princeton. Negaranya yang kedua, Prancis menganugerahinya penghargaan Chevalier de la Legion. ${ }^{46}$

M. Arkoun menghindari hubungan yang erat dengan orientalisme, suatu disiplin yang sering dihubungkan dengan orang-orang Barat yang merendahkan dan mendominasi dunia Islam. Tetapi dia juga menghindari rejim-rejim nasionalistik yang memaksakan politik dan agama ortodoks serta membatasi kebebasan berpikir. Dia lalu bergerak ke pinggiran ilmu sosial Barat untuk membebaskan Islam dari kekeliruan konsep dan persepsi Barat dan pendukungpendukungnya. Untuk itu Arkoun menempatkan dirinya diperbatasan diskursus pemikiran Islam dan bahkan melampauinya. Bagi Arkoun tidak ada yang dapat disebut pinggiran atau pusat, tidak ada kelompok yang terpingggirkan atau yang dominan, tidak ada kepercayaan yang dapat dikategorikan sebagai rendah maupun agung. Pikiranlah yang menciptakan kebenaran. ${ }^{47}$ M. Arkoun juga menganjurkan untuk mempelajari Islam dan memahami kebudayaan Islam dengan menggunakan pendekatan ilmu-ilmu sosial. Latar belakang Arkoun memang bukan dari pesantren atau madrasah, ia dibesarkan dalam sistem pendidikan Barat (Perancis) yang sekuler. Ia terdidik untuk melihat segala sesuatu dengan cara yang kritis dan satu sikap yang skeptis terhadap apa yang

45 John 1. Esposito, John L. Eposito (editor), Ensiklopedi Oxford, Dunia Islam Modern, Bandung, Mizan, 2002, p.

${ }^{46}$ Didin Saefuddin, Biografi Intelektual..., p. 171.

${ }^{47}$ M. Arkoun, Ritingking of ...,p.xi 
dinamakan kebenaran di dalam ilmu. Ia juga berasal dari sebuah keluarga muslim. Meskipun ia hidup di lingkungan Barat tetapi dalam keluarganya terlihat sikap kebudayaan yang islami.

Bertolak dari kesusasteraan dan pengetahuannya tentang peradaban Islam dan Barat, ditambah dengan pengenalannya terhadap ilmu-ilmu sosial (pendekatan interdisipliner ilmu). Arkoun mencoba untuk menjadi pemikir sekaligus juga aktor dilingkungan Islam sebagai agama yang hidup didalam masyarakat yang berkebudayaan majemuk.Setidaknya ada empat pendekatan yang menurutnya patut dipertimbangkan untuk digunakan dalam studi kebudayaan dan peradaban Islam era sekarang, khususnya, dan era studi agama pada umumnya. Pendekatan tersebut adalah pendekatan sejarah, antropologi, sosiologi dan bahasa. ${ }^{48}$

Kebanyakan karya akademik Arkoun berkaitan dengan tirani pemikiran, Barat maupun Islam, serta dampaknya terhadap pandangan umat Islam mengenai dirinya sendiri. Dia sangat kritis baik terhadap Barat maupun Timur yang mempercayai superioritas akal, karena kepercayaan itu sendiri tidak dapat dibuktikan oleh akal. Arkoun mengejek demokrasi Liberal karena menafikan hutangnya pada peradaban Kristen dan menyerang umat Islam yang dengan superioritas ilmu pengetahuan, mengklaim dapat membedakan "kebenaran" Islam dari kesesatan, "kebenaran seorang muslim" dari seorang yang menyebut dirinya sebagai muslim. Arkoun berusaha mengarahkan pikiran-pikirannya antara Universalisme Barat yang cendrung memarjinalkan semua tradisi Islam, dan kebangkitan Islam yang menempatkan diri pada posisi yang aneh baik dipandang oleh tradisi Barat maupun oleh tradisi Islam sebagaimana yang dipahami oleh sebagian umat Islam pada empat belas abad yang lalu. Landasan utama Arkoun adalah sejarah, antropologis, semiotic, sosiologi dan filsafat postmodern. Bagi Arkoun sejarah umat Islam sangat berkaitan dengan sejarah

48 Amin Abdullah, Arkoun dan Kritik Nalar Islam", dalam Tradisi, Kemoderenan dan Metamodernisme, Yogyakarta, LKIS, 1996. p. 1-21. 
Barat. Tidak ada dikhotomi antara pemikiran Barat dan Islam. Keduanya telah saling menyatu dan harus dihargai sekaligus dievaluasi. ${ }^{49}$

Titik sentral pemikiran Arkoun, menurut M. Amin Abdullah, yang dikutif Didin terletak pada kata kuci kritik efistimologis. Istilah ini digunakan dalam berbagai karyanya meski dalam konteks yang berbeda-beda. Pemahaman dan makna kritik efistemologis dalam konsep Arkoun terasa menukik dan menyengat lantaran kritik efistemologis itu ditujukan pada bangunan keilmuan ilmu-ilmu agama secara keseluruhan. Struktur dan bangunan keilmuan agama (Islam) dilihatnya sebagai produk sejarah pemikiran keagamaan biasa yang sebenarnya hanya berlaku pada penggal waktu dan ruang tertentu. Meski nilai-nilai dan ajaran agama Islam sering disebut sebagai bersifat transendental universal, jika nlai-nilai itu dipraktikan dalam kehodupan masyarakat tertentu yang notabene terkurung oleh kepentingan sosial-politik-ekonomi tertentu, nilai tersebut tidak lagi bersifat transcendental dalam arti yang sebenarnya. Mau tidak mau warna lokal juga ikut membentuknya. ${ }^{50}$ Nalar Islam yang dimaksud oleh Arkoun adalah nalar ortodoksi, efistemologi, skolastik, atau pemikiran Islam klasik. Sejarah pemikiran Islam pada umumnya katanya memang belum mengalami proses aufklarung atau renaissance, atau dengan kata lain ungkapan belum pernah melampaui tahapan kritik efistimologis yang cukup mendasar. Hal demikian terjadi oleh karena latar belakang kemenangan pemikiran teologi klasik ortodok diatas pemikiran kritis-filosofis yang terjadi diseputar kontroversi Al-Ghazali dan Ibnu Sina. Sejak itu pemikiran teologi ortodok menjadi teken for granted sehingga tidak diperlukan kajian atau rumusan ulang, yang dipentingkan hanya pengulangan-pengulangan yang tidak perlu hingga saat ini. Akibatnya pemikiran muslim sulit untuk membedakan antara mana aspek yang dianggap ta'abbudynormatif dan mana aspek yang dianggap sebagai pemikiran manusia biasanya yang sebenarnya tidak lain adalah hasil rekayasa tuntutan sejarah kemanusiaan

\footnotetext{
${ }^{49}$ M. Arkoun, Ritingking of ..., p.xix

${ }^{50} \mathrm{Ibid}$., p. 5 yang dikutip Didien Saifuddin, Biografi Intelektual..., p.173.
} 
yang bersifat "relative". ${ }^{51}$ Satu hal yang perlu dicatat katanya bahwa tradisi pemikiran Islam klasik -ortodok tidak mengenal tradisi kritik efistimologis dalam artian yang sesungguhnya.. ${ }^{52}$ Keprihatinan Arkoun ditimbulkan oleh persoalan bahwa mengapa ilmu-ilmu agama Islam, seperti fiqh, kalam, falsafah, tafsir, tasawuf tetap seperti itu adanya, baik dari segi bentuk, mautan maupun metodologisnya. Sejak ilmu itu disusun, belum ada perubahan-perubahan yang cukup berarti. Lagi pula format, isi dan metodologi yang tidak berubah dan tidak bertahan seperti sediakala itu pulalah yang masih diikuti, dipelajari dan ditekuni sampai sekarang. Padahal kehidupan manusia telah berubah sedemikian fantastisnya, baik dari segi kualitas maupun kkuantitas, dari segi intensitas maupun ekstensitasnya. ${ }^{53}$

Dengan cara membongkar bangunan efistemologi keilmuan agama Islam era klasik-skolastik, agaknya Arkoun ingin mengembalikan wacana keagamaan Islam pada wacana dan dataran Qur'ani yang lebih mendasar, mendalam dan substansial. Sebuah wacana yang memuat nilai-nilai normativitas, spiritualitas, dan moralitas keberagamaan Islam yang terbuka, mendasar sekaligus fungsional, tanpa harus dibebani terlalu berat beban-beban dan muatan ideology politik. ${ }^{54}$ Untuk mengembalikan "keseimbangan" antara bobot pemikiran teologis Islam klasik yang lebih bermuatan moralitas-normatif dan tuntutan ilmu pengetahuan kontemporer yang bersifat empiris kata Amin Abdullah diperlukan kritik epistimologis yang cukup mendasar. Tahapan ini perlu diperkenalkan dan dilalui sebelum melangkah kepada hal-hal yang bersifat operasional ${ }^{55}$ Untuk melihat dan mengungkap kembali autentisitas spiritualitas dan moralitas keberagamaan Islam, seorang muslim harus berani melakukan "pembongkaran" terhadap struktur tersebut dengan menyimak kembali ajaran-ajaran Qur'ani secara lebih

${ }^{51}$ Dr.M. Amin Abdullah, Falsafah Kalam diEra Post Modern, Yogyakarta, Pustaka Pelajar, 1997, p. 55.

\footnotetext{
${ }^{52}$ Ibid., p.55

${ }^{53}$ Ibid., p. 9-10

${ }^{54}$ Ibid., p. 17

${ }^{55}$ Ibid., p. 59
} 
arif dan konprehensif. ${ }^{56}$ Menurut Amin Abdullah, jasa yang perlu dicatat dari Arkoun adalah peringatannya terhadap seluruh umat beragama, khususnya Islam, bahwa antar kedua wilayah, yakni historisitas-kekhalifahan dan normativitas spiritualitas perlu dihubungkan secara terus menerus sehingga terjadi proses saling koreksi dan kehidupan beragama manusia tidak akan stagnan pada satu sisi saja. Menurut Komaruddin Hidayat, yang dikutip Didin, salah satu aspek pemikiran Arkoun yang sangat berharga adalah usahanya untuk memperkenalkan pendekatan hermeneutika, sebuah metodologis kritis. Dalam karya-karya Arkoun ditemukan wacana kritis dari tiga sumber utama, yaitu visi Qur'an, kitab-kita Islam klasik, dan filsafat Barat kontemporer yang sering dikategorikan sebagai pemikiran pascamodernisme. ${ }^{57}$ Berdasarkan cara pandang Arkoun, data kehidupan generasi awal Islam yang disajikan dalam buku-buku klasik, seperti kitab Al-Maghazi, karya Muhammad al-Waqidi, Sirah Rasul Allah karya Muhammad Ibn Ishaq, Tarikh al-Thabari dan al-Tabaqat al-Kubra karya Ibn Sa'ad, akan memunculkan informasi dn makna baru ketoka didekati dengan cara pandang baru, terutama dengan menggunakan metode hermeneutika histories. Karena setiap pengarang, teks dan pembacanya tidak bisa melepaskan diri dari konteks social, politis, psykologi, teologi dan konteks lainnya dalam ruang dan waktu tertentu, hal yang diperlukan alam, memahami sejarah bukan hanya transper makna, malainkan juga transpormasi makna. Arkoun berusaha melakukan pembaharuan dalam memahami Islam dengan memanfaatkan perkembangan ilmu pengetahuan sosial Barat modern., terutama kritik sejarah dan kritik sastra yang berkembang dalam tradisi intelektual Prancis dan Jerman. ${ }^{58}$ Arkoun barangkali merupakan satu-satunya ilmuan dan ilmuan muslim yang telah mencoba memperkaya studi Islam dengan hasil perkembangan semiotika. Manfaat analsisi semiotik dalam analisisi al-Qur'an menurutnya adalah bahwa

\footnotetext{
56 Ibid.,

${ }^{57}$ Didin Saifuddin, Biografi Intelektual..., p. 174

${ }^{58}$ Ibid., p. 175
} 
pendekatan semiotik memandang suatu teks sebagai keseluruhan dan sebagai suatu system dari hubungan-hubungan intern. Kelebihan lain adalah bahwa analisis semiotik membuat kita mendekati suatu teks tanpa interpretasi tertentu sebelumnya atau praanggapan lain. ${ }^{59}$

Arkoun memandang perlunya dikuasai Islamologi Terapan. Hal ini disebabkan Islamologi Kalsik tidak lain dari sebuah penilaian dan pengertian orang Barat terhadap Islam, Islamologi Klasik menurut Arkoun sexara praktis mempersempit ruang-ruang studinya pada pemikiran-pemikiran logosentriste (teologi, hokum, filsafat) yang dibaut dalam perspektif idealis sejarah gagasangagasan. Hubungan yang begitu kaya antara Islam sebagai fenonmena agama disatu sisi dan manusia disisi yang lain belum dikaji secara mendalam dan konprehensif. $^{60}$ Jika dicermati dari kedua tokoh pemikir dan pembaharu Islam sebagaimana disebutkan di atas, nampaknya banyak sekali pemikiran-pemikiran yang amat berharga dan konstruktif yang dapat dikembangkan untuk kemajuan dalam dunia islam baik di masa sekarang maupun di masa yang akan datang. Pertama, Fazlurrahman merupakan seorang sosok agamawan sekaligus ilmuan yang memiliki keberanian di dalam melahirkan pemikiran-pemikiran yang berbeda bahkan controversial. Menurutnya pemikiran yang controversial merupakan bagian dari konsekwensi dan kreativitas intelektual, bahkan menurutnya perbedaan merupakan sebuah konsekwensi logis yang tidak dapat dihindari dalam kehidupan ini. Kedua, ia juga mengajarkan kepada generasi sesuadahnya untuk memiliki semangat dan etos belajar yang tinggi sebab hampir seluruh waktunya digunakan untuk belajar, mengajar dan menulis. Ketiga, ia juga merupakan seorang pemikir yang mengajarkan kepada intelektual muslim akan pentingnya menghargai sejarah Islam masa lalu bahkan menurutnya suatu bentuk pengembangan pemikiran Islam yang tidak berakar dalam kejayaan

${ }^{59}$ J.H. Meuleman, "Islam dan Pascamodernisme dalam Pemikiran M. Arkoun", yang dikutip Didin Saefudin, Biografi..., p. 177

${ }^{60}$ Ibid.,..., p. 178. 
pemikrian Islam klasik atau luput dari kemampuan menelusuri benang kesinabungan dengan masa lalu adalah tidak aotentik. Pengembangan pemikiran Islam yang tidak melihat kontinuitas dengan masa lalu, Islam akan kehilangan aotensitasnya yang berakibat akan tidak mampu mengembangkan dinamika internalnya serta tidak sanggup bertahan karena kekurangan segi kemantapan. Pemikiran seperti itu akan mudah kehilangan energi, dan dengan begitu juga berarti terancam untuk lekas padam. Disamping itu menurut Fazlurrahman mengabaikan sejarah masa lalu tidak saja mengisyaratkan pengingkaran akan eksistensi sejarah itu sendiri, tetapi juga bisa mengakibatkan masyarakatnya akan kehilangan eksistensi diri dan sistem keyakinan dalam kerangka sejarah masa kini. Karena itu Fazlur Rahman adalah sosok pemikir yang sangat teguh memegang prinsip "memelihara yang lama yang baik, dan mengambil yang baru yang lebih baik. Keempat, Fazlurahman merupakan pemikir NEOMODERNISME, yaitu suatu pola pemikiran yang menggabungkan antara pemikiran modern dan tradisional. Modernisme menurutnya, bukanlah sesuatu yang harus ditolak, melainkan dengan modernisme bukan pula berarti alam pemikirian tradisionalisme harus di kesampingkan. Kelima, ia juga mengajarkan bahwa al-Qur'an sebagai sumber ajaran moral yang sempurna dipahami secara utuh dan padu. Pemahaman yang benar dan utuh ini harus dikerjakan melalui suatu metodologi yang dapat dipertanggungjawabkan secara agama dan secara ilmu. Menurut Rahman, tanpa suatu metodologi yang akurat dan benar, pemahaman terhadap kandungan al-Qur'an boleh jadi menyesatkan, apalagi bila didekati secara parsial dan terpisah. Hal ini sejalan dengan pemikiran Syekh Muhmmad Kutub yang mengatakan bahwa salah kesalahpahaman terhadap ajaran Islam disebabkan karena beberapa 1). Salah memahami ruang lingkup agama Islam; 2) Salah menggambarkan segmen-segmen atau bagian-bagian kerangka keseluruhan ajaran agama Islam dan 3). Salah dalam mempergunakan metode pengkajian Islam. 
Rahman juga menambahkan bahwa Al-Qur'an dan keagamaan Islam (normativitas dan historisitas) harus dilihat dari dua sisi secara utuh sebab jika tidak demikian akan terjadi proses dominasi yang satu atas yang lain, sehingga menepikan aspek "historis" kemanusiaan atau sebaliknya akan menepikan aspek "normativitas" yang dihayati oleh para pemeluk agama. Ia juga berpandangan bahwa kondisi umat Islam tidak akan lepas dari berbagai masalah, kesulitan dan ketertinggalan kecuali jika umat Islam kembali dan berpegang pada Al-qur'an. Hal ini tampaknya senada dengan ungkapan Syekh Jamaluddin al-Afghani dan Syeikh Muhammad Abduh pernah menyatakan bahwa "kaum Muslimin mundur dalam segala hal lantaran meninggalkan kitab sucinya (al-Qur'an) dan bangsa Eropa maju, lantaran meninggalkan kitab suci mereka (Biyble). Lebih lanjut menurut Rahman mengenai konsep Islam mengenai Negara (pemerintahan), nampaknya lebih cenderung berpendapat bahwa Islam tidak mengajarkan secara jelas mengenai sistem kenegaraan tetapi mengakui bahwa terdapatnya sejumlah tata nilai dan etika dalam al-Qur'an. Ia juga menyatakan dengan tegas bahwa "antara agama dan politik tidak bisa dipisahkan. Fazlur Rahman juga menyatakan bahwa Islam memerintahkan agar persoalan-persoalan kaum muslimin ditanggulangi melalui syura atau konstitusi timbal balik. Hal ini juga sesuai dengan al-Qur'an dan Hadis-hadis Nabi Saw. Ia juga menegaskan bahwa kebebasan untuk mengemukakan pendapat dan kritik yang konstruktif yang ditujukan kepada pemerintah dianggap sebagai tugas keagamaan. Tetapi ia juga tidak dibenarkan sikap yang bernada subversive dan yang dapat menimbulkan kebencian serta menghasut rakyat untuk menggulingkan pemerintahan yang sah dengan cara-cara yang tidak konstitusional dan dengan menanamkan perasaan putus asa kepada rakyat. Dalam hal pendidikan ia menawarkan pendekatan pembaharuan pendidikan adalah dengan menerima pendidikan sekular modern seperti yang telah berkembang pada umumnya di Barat dan mencoba untuk "mengislamkan"nya, yakni dengan mengisinya dengan konsep-konsep kunci tertentu dari ajaran Islam. Ia juga sangat mendukung ide Islamisasi Ilmu 
Pengetahuan. Menurutnya, upaya menamakan watak Islam dalam diri pelajarpelajar muslim tidak akan berhasil apabila bidang-bidang ilmu pengetahuan pada taraf yang lebih tinggi dibiarkan sepenuhnya sekuler, yaitu tanpa tujuan dalam kaitannya dengan efeknya bagi masa depan umat manusia.

Selanjutnya dari pemikiran yang digagas oleh Muhammad Arkoun, terdapat beberapa poin penting yang dapat dikembangkan untuk kemajuan umat Islam dimasa sekarang dan bahkan dimasa yang akan datang, yakni ;

Pertama, bahwa untuk memahami Islam memahami Islam yang universal dan multi dimensi hendaknya dipahami dengan menggunakan multi pendekatan, sebab kalau hanya dipahami dengan menggunakan satu pendekatan, maka yang akan tanpak dari islam hanya bagian-bagian tertentu saja. Diantara pendekatan yang ditawarkan Arkoun adalah dengan pendekatan ilmu social dan budaya.

Kedua, Penelitian agama menurut Arkoun tidak bisa dipisahkan dari pendekatan psikoanalisa, psikologi (individual, social), sejarah, sosiologi (tempat Islam di dalam apa yang dinamakan le system d'action historique, system aksi histories dari masyarakat dan pengaruhnya terhada Islam sebagai agama), kebudayaan, (kesenian, kesusteraan dan pemikiran). Arkoun juga menekankan Pendekatan Islam sebagai faktor integrasi msosial dan kebudayaan, resisten dan pertentangan terhadap integrasi itu sendiri.

Ketiga, menurut Arkoun bahwa selama ini Barat cenderung menempatkan posisi Islam pada posisi yang marginal, karena itu untuk kemajuan umat Islam ke depan umat Islam menurutnya umat Islam harus membuka diri dengan pemikiran-pemikiran Barat bahkan dapat memadukannya. Selanjutnya menurutnya pemikiran-pemikiran keagamaan yang dilahirkan oleh umat Islam, dalam satu kurun waktu tertentu, karena itu, pemikiran-pemikiran keagamaan yang lahir tersebut hendaknya dapat menjawab setiap perubahan zaman yang ada. Disamping itu, untuk melihat dan mengungkap kembali autentisitas spiritualitas dan moralitas keberagamaan Islam, seorang muslim harus berani melakukan "pembongkaran" terhadap struktur tersebut dengan menyimak 
kembali ajaran-ajaran Qur'ani secara lebih arif dan konprehensif. Aspek pemikiran Arkoun yang lain adalah usahanya untuk memperkenalkan pendekatan hermeneutika, sebuah metodologis kritis. Dalam banyak karyanya Arkoun juga menggunakan analisis semiotika. Semiotika adalah ilmu tanda atau signifikansi. Menurutnya tanda memainkan peran penting dalam agama. Pertama, dalam agama Islam, dunia ciptaaan dengan berbagai aspeknya sering digambarkan sebagai tanda Allah. Kedua, kitab-kitab wahyu yang menjadi salah satu dasar kebanyakan agama dapat dianggap sebagai himpunan tanda yang menunjukan makna tertentu dan perlu digali dalam proses penafsiran. Manfaat analisis semiotik dalam analisisi al-Qur'an menurutnya adalah bahwa pendekatan semiotik memandang suatu teks sebagai keseluruhan dan sebagai suatu sistem dari hubungan-hubungan intern. Kelebihan lain adalah bahwa analisis semiotik membuat kita mendekati suatu teks tanpa interpretasi tertentu sebelumnya atau pra anggapan lain. Ia juga mengajurkan umat Islam untuk menguasai Islamologi Terapan. Hubungan yang begitu kaya antara Islam sebagai fenonmena agama disatu sisi dan manusia disisi yang lain belum dikaji secara mendalam dan konprehensif.

\section{E. Kesimpulan}

Dari beberapa pemikiran Fazlur Rahman dan Muhammed Arkoun, diatas, maka dapat ditarik kesimpulan secara garis besar: Fazlur Rahman adalah termasuk salah seorang tokoh pemikir Isalam kontemporer yang berasal dari Pakistan yang oleh para pengamat pemikiran dikelompokkan sebagai pemikir neomodernis. Fazlurrahamn juga amat kritis dalam melihat pemikiran Islam yang lepas dari konteks "Normativitas" dan "Historisirtas"nya. Ia juga berpandangan bahwa pengembangan pemikiran Islam harus selalu berakar dari pemikiran Islam klasik. Menurut Fazlur Rahman, kendatipun tidak menyatakan secara gamblang pendapatnya mengenai konsep Islam mengenai Negara (pemerintahan), nampaknya lebih cendrung berpendapat bahwa Islam tidak mengajarkan secara jelas mengenai system kenegaraan tetapi mengakui bahwa 
terdapatnya sejumlah tata nilai dan etika dalam al-Qur'an. Fazlurrahamn juga mempunyai perhatian yang besar terhadap masa depan pendidikan Islam dan bahkan ia menawarkan suatu pandangan bahwa oreientasi pendidikan sangat perlu diwarnai dengan nilai-nilai Islam sehingga para pelajar muslim dan pengetahuan yang dihasilkan tidak menjadi sekuler. Muhammad Arqoun merupakan salah satu tokoh pemikir Islam kontemporer yang berasal dari Aljazair. Umat Islam menurut M. Arkoun perlu memperdalam Islam melalui pendekatan ilmu social, antroologi, dan kesusanteraan agar memperoleh pemahaman yang konperhensif tentang Islam. Islamologi klasik nampaknya perlu dikaji dan dipahami secara mendalam lagi agar mampu berisnteraksi dengan perubahan zaman.

\section{Daftar Pustaka}

Abdul Halim (ed.) Teologi Islam Rasional Apresiasi terhadap Wacana dan Praksis Harun Nasution, Jakarta, Ciputat Press, 2001

Abuddin Nata. Metodologi Studi Islam, Jakarta: Raja Grafindo Persada, 1998

Ahmad Syafi'i Ma'arif, (kata pengantar), Islam dan Modernitas, Bandung, Mizan, 1995

Ali, Muhammad Daud, Pendidikan Agama Islam, Jakarta, PT. Raja Grafindo Persada, 1998.

Dadang Kahmad. Sosiologi Agama, (Bandung: Remaja Rosdakarya, 2002

Depag RI. Al-Qur'an dan Terjemahnya, , Jakarta, Penerbit J-Art, 2004.

Didin Saifuddin, Biografi Intelektual 17 Tokoh Pemikrian Modern dan Postmodern Islam, Jakarta, 2003

Fazlur Rahman, Islam, Bandung, Pustaka, 2003

Fachri Ali dan Bahtiar effendi, Merambah Jalan Baru Islam, Bandung, Mizan, 1986

John L. Eposito (editor), Ensiklopedi Oxford, Dunia Islam Modern, Bandung, Mizan, 2002, jil.3 
M. Amin Abdullah, Falsafah Kalam di Era Modern, Yogyakarta, Pustaka Pelajar, 1997

Dr. Arkoun dan Kritik Nalar Islam", dalam Tradisi, Kemoderenan dan Metamodernisme, Yogyakarta, LKIS, 1996.

Muhamad Arkoun, Dr. Rethingking of Islam, (penerjemah) Yudian W. Yasmin dan Lathiful Khuluq, Yogyakarta, LPMI dan Pustaka Pelajar, 1996, cet. I

Mansur. Peradaban Islam dalam Lintasan Sejarah, (Pengantar). Prof.DR. TH. Ibrahim Alfian, MA, Yogyakarta, Global Pustaka Utama, 2004

Muhaimin, Dimensi-Dimensi Studi Islam, Surabaya, Karya Abditama, 1994.

Muhammad Daud. Pendidikan Agama Islam, Jakarta, PT. Raja Grafindo Persada, 1998

M. Hasbi Amirudin, Konsep Negara menurut Fazlur Rahman, (pengantar) Deliar Noer, Yogyakarta, UII Press, 2000, cet. Ke-1

Nasution, Harun, Prof. DR. Islam ditinjau dari Berbagai Aspeknya, Jakarta, UI Press, 1986

Nurchalish Madjid, Fazlur Rahman dan Rekonstruksi Etika Al-Qur'an, dalam Jurnal Islamika, no. 2, 1993.

Tashwirul Afkar, Jurnal Refleksi Pemikiran Keagamaan dan Kebudayaan, Jakarta, Lakpesdam NU, 2000

Taufik Adnan Kamal, Metode dan Alternatif Neomodernisme Islam Fazlur Rahman, Bandung, Mizan, 1989

W. Montgomery Watt, Islam dan peradaban Dunia, Pengaruh Islam Atas Eropa Abad Pertengahan, (Pengantar). Dr. Nurcholish Madjid, Jakarta, PT. Gramedia Pustaka Utama, 2004

Wan Muhammad Nor Wan Daud, "Fazlur Rahman, Kesan Seorang Murid dan Teman". Jurnal Ulumul Qur'an, No. 8 tahun 1991.

Toyib I.M. dan Sugianto. Islam dan Pranata Sosial Kemasyarakatan, Bandung: PT. Remaja Rosdakarya, 2002 